\title{
UNIFICATION VS. LOCAL AUTONOMY: EVOLUTION OF LAW IN BALTIC PROVINCES UNDER RULE OF THE GREAT POWERS IN 16TH - 19TH CENTURY
}

\author{
Valdis Blūzma \\ Dr. hist., Professor \\ Turiba University (Riga, Latvia) \\ Email;valdisbl@yahoo.com
}

\begin{abstract}
The impact of policies pursued by the neighbouring great powers on the evolution of law in the Baltic provinces in the 16th - 19th centuries is a little-studied topic of legal history. Although a number of studies of Estonian, Latvian, Finnish, German, Russian, English, and American scholars have been published in recent decades that touch upon various aspects of this topic, there is still no general analysis of the factors that caused the transition of policy of Polish-Lithuanian Commonwealth, Kingdom of Sweden and Russian Empire from the principle of preserving the administrative and legal autonomy of the Baltic provinces to a gradual unification of their administrative and legal system. The comparison of legal policy of these great powers in Baltic provinces facilitate the better understanding of the common features and differences of legal policies implemented by these states in Baltic region. The author concludes that the promises made by rulers of the great powers to observe and protect previous laws of newly acquired Baltic provinces slowed down the further development of these territories in the field of law, which became especially clear in the 19th century, when the Russian government began to extend the force of its modern laws to the Baltic governorates. The new national states, which were founded in 1918 in place of the former Baltic governorates - Latvia and Estonia - were not bound by the promises to respect the previous law and were able to abolish the privileges of Baltic German nobility and modernize law by eliminating territorial particularism.
\end{abstract}

Keywords: Baltic provinces, administrative autonomy, legal autonomy, local law, unification of law, majesty clause

\section{Introduction}

This article is devoted to the analysis of the struggle between two trends in policy of the great powers in relation to legal autonomy of Baltic provinces (territory of modern time Latvia and Estonia) in $16^{\text {th }}-19^{\text {th }}$ centuries. The first of these trends was the preservation of the local law, which was in effect at time when territories of the Baltic provinces were included into the empires of the neighbouring great powers, but the second trend may be characterized as a gradual unification, i.e. attempts, more or less successful, to replace the local law by law of great power. 
History of European states in early period of modern history $(1500-1815)$ is marked by large number of armed conflicts, which were often generated by the imperialistic aspirations of powerful states to seize new territories, obtaining new natural resources, prospective trade routes, the infrastructure of the conquered territories, and their population as new human resources. The annexation of new territories required the settlement of different legal issues both the delimitation of the new borders of the victorious state in a peace treaty with the defeated state, and also issues of administrative system at newly acquired territory, official language of its local administrative and judicial bodies, freedom of religion for new subjects of victorious state, applying of previous laws and customs, warranties for the former rights of subjects and privileges of nobility and burghers.

For Livonia (confederation (Staatenbund) of five ecclesiastical states established in $13^{\text {th }}$ century as a result of crusade from Holy Roman Empire in territory of modern Estonia and Latvia) these issues became actual in the middle of $16^{\text {th }}$ century because it was not able to repel the military offensive launched by Tsar of Russia Ivan IV after the declaration of war against Livonia in 1558. In order to avoid the conquest of the country by despotic Ivan the Terrible and not having any military support from the decentralized Holy Roman Empire, the rulers of different parts of Livonia decided to submit voluntarily to the neighbouring states - Grand Duchy of Lithuania and Kingdom of Sweden in order to protect the territory of country from Russian invasion.

\section{Legal policy of Poland-Lithuania in Livonian province in $16^{\text {th }}-17^{\text {th }}$ centuries}

On $28^{\text {th }}$ of November 1561 in Vilnius (Wilno) King of Poland and Grand Duke of Lithuania Sigismund II Augustus and last Master of Livonian Order Gotthard Kettler signed a Pact of Subjection (Pacta subiectionis). ${ }^{1}$ By this treaty Livonian Confederation was liquidated, and in the southern part of its territory the secular vassal state - Duchy of Courland and Semigallia (usually named as Duchy of Courland) was established under supreme power (dominium directum) of Polish king and Grand Duke of Lithuania as overlord. Gotthard Kettler became the first Duke of Courland with the dynastic right of his male descendants to hereditary fief of the Duchy of Courland. ${ }^{2}$

The northern part of the Livonian Confederation over the Daugava River was transferred under the direct authority of the Polish king and the Grand Duke of

\footnotetext{
1 See original Latin text of Treaty of Vilnius in: Dogiel, M., Codex Diplomaticus Regni Poloniae et Magni Ducatus Lituaniae, Tomus V, Vilnae, MDCCLIX, Doc. CXXXVIII, pp. 238 - 243; Ziegenhorn von, Ch., Staatsrecht der Herzogthümer Curland und Semigallen, J.J.Kanter, Königsberg, 1772, pp. 51 -56 .

2 Евстратьев, О., Курляндское гериогство в политической системе Речи Посполитой (вторая половина XVI - конеи XVIII вв.), Беларускі гысторічны зборнік, №. 47, 2017, pp. 45 - 47.
} 
Lithuania and received the name of the Livonian province and the title of TransDaugava Principality (Ducatus Ultradunensis). However, Baltic German knighthood of the northern part of modern time Estonia and burghers of Reval (now Tallinn) decided to submit to the authority of Sweden in June of $1561,{ }^{3}$ but the Polish king did not recognize the legitimacy of this act in Pact of Subjection considering that he had the exclusive rights on all the territory of Livonian Confederation because Master of Livonian Order and bishops of Livonian bishoprics recognised his authority.

The Pact of Subjection contained the obligation of Polish king do not obstruct the freedom of the Lutheran church in Livonian province, as well as, to observe the rights, freedoms and privileges of the nobility and clergy. A readiness to recognize "jurisdiction in general according to ancient laws, customs and habits" was also declared in this treaty by the ruler of Poland and Lithuania manifesting legal autonomy for Livonian province. Pact of Subjection also stipulated principle of Ius indigenatus (right of local birth - Lat.) for Livonian province, declaring that the local offices would continue to be "reserved only to people of German descent and language and certainly to the locals".

However, the treaty contained a reservation that the privileges of Livonian Germans for office would be fully recognized only after the Livonian War, until then Poles or Lithuanians, or people of other nationalities who had proved their courage, trust and loyalty to ruler of Poland and Lithuania could become administrators of castles and fortresses. The next Polish rulers did not keep this promise. Sejm constitutions (legislative acts issued by Diet of Polish-Lithuanian Commonwealth) of 1589 prescribed that only Poles or Lithuanians could be the administrators of starosties (local territorial administrative units of Polish-Lithuanian Commonwealth) in Livonian province ${ }^{4}$ which after Lublin Union of 1569 became a condominium of both Kingdom of Poland and Grand Duchy of Lithuania.

Simultaneously with Pact of Subjection Sigismund II Augustus also approved Privilege for knighthood of Livonian Order "Privilegium Sigismundi Augusti" in which the request for a new codification of Livonian law by vassals of the Livonian Order was included asking that "certain and general provincial laws be drawn up we therefore ask you again and again to appoint certain men who know the laws so that they may collect and put in place such draft provincial laws and, once all the Livonian estates have agreed to it, bring them before Your Saint Royal Majesty to review, approve and promulgate it."

\footnotetext{
${ }^{3}$ Dogiel M., op. cit., Doc. CXXXVII, pp. 236 - 238; Russow, B., Chronica der Prowintz Lyfflandt, Bart, s.l., 1584, pp. 64 - 66; Rusovs, B., Livonijas kronika, Aka, Grand Haven, 1976, pp. 88 - 90.

${ }^{4}$ See original Polish text of Sejm constitutions of 1589 in: Volumina Legum. Przedruk zbioru praw staraniem XX. pijarów w Warszawie, od roku 1732 do roku 1782, wydanego. Tom II, J. Ohryzko, Petersburg, 1859, pp. $277-280$.

${ }^{5}$ See original Latin text of Privilegium Sigismundi Augusti in: Dogiel, M., op. cit., Doc. CXXXIX, pp. $243-248$.
} 
However, it took a long time before such permission of a codification of local law was given to Livonian province. There was an attempt in Sejm constitutions of 1589 to transplant a foreign law in Livonia - Magdeburg law for cities and Saxon law for rural regions which were unknown in Livonia but were applied in Poland. This attempt to unify Livonian law with Polish law proved unsuccessful, as it caused outrage among the Livonian Germans, because it clearly contradicted to the privilege granted to Livonia by the Polish king's acts of 1561 and $1566^{6}$ to draw up a code of law from ancient laws of the province. ${ }^{7}$ In 1598 , Livonian province was finally allowed to codify its laws. Following an agreement reached by a commission sent by Polish king Sigismund III Vasa with the nobility of Livonian province, the work of editing of the codification was assigned in March 1599 to David Hilchen, a prominent lawyer from Riga. In five months, David Hilchen drafted a project entitled "Livonian Land Laws and Constitutions" (Liefländische Landt-Rechte und Constitutiones). However, the final reviewing and approving of this draft-code was postponed from Warsaw Sejm of 1600 to the next Sejm, but Sigismund III allowed provisional applying of it. $^{8}$ The outbreak of the Polish-Swedish war in 1600 prevented the completion of the procedure for the entry into force of this draft-code which never came in effect, but it was applied in Livonian province in early years of $17^{\text {th }}$ century as judges and notaries of voivodship's courts received an instruction to decide disputes "according to the new land law". 9

After the unsuccessful outcome of the war, Poland was forced to hand over most of the Livonian province with its capital Riga to Sweden, retaining by the terms of the Olive Peace Treaty (1660) only a smaller south-eastern part of the Livonian province under its power known as Polish Inflanty ${ }^{10}$ (now Latgale region in eastern part of Latvia). ${ }^{11}$ After regaining of its territory from Russia in 1667, Poland actively stimulated the polonization and recatolization of privileged estates. The Ordinance of Duchy of Inflanty which was issued by Polish Sejm in 1677 stated that henceforth in the territory of the Duchy of Inflanty (this title of Inflanty Voivodeship was established in 1677) the laws adopted by Sejm and the Statute of the Grand Duchy of Lithuania (the 3rd edition, issued in 1588) must be applied by local authorities and courts. ${ }^{12}$ Consequently, the previous laws from times of the Livonian Confederation and draftcode by Hilchen became invalid. Thus, by this act of unification of law Inflanty or Polish Livonia lost its legal autonomy and was included into legal space of Lithuania.

\section{Local and Swedish law in Swedish Livonia $\left(17^{\text {th }}\right.$ century - early $18^{\text {th }}$ century)}

A similar trend from the recognition of the autonomy of local law to the gradual unification of law by extending the application of law of great power was also seen in those regions of previous Livonian Confederation which in the $16^{\text {th }}$ and $17^{\text {th }}$ centuries

12 See original Polish text of ordinance "Ordynacya Xięstwa Inflanstkiego" in: Volumina Legum, T. V, J. Ohryzko, Petersburg, 1860, p. 237. 
came under Swedish rule. The first attempt on unification of law was made already in 1600 - 1601, when the Swedish regent, Duke Karl of Södermanland, proposed to the nobility of the Estonian, as well as, Livonian province, which had just been conquered by Swedish army, to adopt Swedish land laws. However, the nobility of both provinces rejected this proposal, noting that they want to keep their local laws forever. ${ }^{13}$

It should be noted, however, that Swedish kings recognised in general terms the earlier rights, freedoms and privileges of knighthood and landed gentry, as well as, burghers including the right to their property and possessions. The first General Confirmation to Livonian nobility rights and privileges was given by Gustav II Adolph in $1629,{ }^{14}$ but privileges and rights of Riga burghers were confirmed in so called Corpus privilegiorum Gustavianum in $1621 .{ }^{15}$

After strengthening of Swedish administration in Livonian province (now southern Estonia and central region of Latvia) in twenties of $17^{\text {th }}$ century Swedish law was prescribed as a subsidiary source of law in Swedish Livonia by Royal ordinance on establishing of High Court for Livonia (Königliche Hofgerichtsordnung für Livland) of $6^{\text {th }}$ September 1630. ${ }^{16}$ In 1709, Swedish land law (Landslag, 1608) and city law (Stadtslag, 1618) were translated into German and published in Riga to make them more comprehensible to lawyers and judiciary in Swedish Livonia. ${ }^{17}$ The Baltic Germans, however, considered that the force of the of supplementary law must be recognised to the modern use of Roman law (usus modernus pandectarum, heutiges römisches Recht) as it was in judicial practice from the last period of Livonian Confederation. ${ }^{18}$ This discrepancy between procedure law regulations of Swedish Livonia and judicial practice of local courts has been noted by Finnish legal historian Heikki Pihlajamäki, who pointed out that Swedish law had been

13 Историческія свъденія об основаніях и ходъ мъстнаго законодательства губерній Остзейскихъ, pp. 140, 161 - 162.

14 Schwedisch-Königliche Bewahrungs-Bestätigung der Privilegien und Rechte der Livlandischen Ritterschaft, Anno 1629. - Buddenbrock, G.J. v. (editor), Sammlung der Gesetze, welche das heutige Livländische Landrecht enthalten, kritisch bearbeitet. Bd. II. Aeltere hinzugekommene Landesrechte, Abt. I, Landesordnungen vom Jahr 1621 bis 1680, Häcker, Riga, 1821, pp. 3 - 4.

15 Geschichtliche Uebersicht der Grundlagen und der Entwickelung des Provinzialrechts in den Ostseegouvernements. Besonderer Theil, Drukerei der Zweiten Abtheilung S.K.M. Eigener Kanzellei, St. Petersburg, 1845, pp. 153 - 155.

16 See 25.§ of Königliche Hofgerichtsordnung für Livland in German in: Buddenbrock, G.J. v. (editor), op. cit., pp. $52-53$.

17 Das Schwedische Land- und Stadt-Recht. G.M. Nöller, Riga, 1709. As noted in legal studies, this publication has facilitated the application of Swedish law in the courts of Livonian province after it became part of the Russian Empire in $18^{\text {th }}-19^{\text {th }}$ centuries. See: Luts, M., Private Law of the Baltic Provinces as a Patriotic Act, Juridica International, No. 1, 2000, p.163.

18 Kalniņš, V., Latvijas PSR valsts un tiesību vēsture. I, Zvaigzne, Rīga, 1972, p. 177. 
applied infrequently in Livonian courts, mentioning duel ordinances of $1680^{19}$ and the prohibition of judicial torture in courts of Livonia by Charles XI in $1686^{20}$ as most obvious exceptions. One can agree to the conclusion of H. Pihlajamäki that "legal practice reveals that Swedish statutory law gained only limited influence in Livonia". 21

Original feature of Swedish law was that it did not know the institute of serfdom that existed in Swedish Livonia. Swedish government also had made several attempts to free the peasants in Livonia. The last one was made by Charles XI which proposal on abolishing of serfdom "in the name of justice and good virtues" was submitted by his representative Major General Robert Lichton to Landtag (provincial assembly of Livonian knighthood) in 1681 but Landtag rejected this proposal as dangerous and premature. ${ }^{22}$

In order to prevent the replacing of local law by Swedish one, the Landtag deputies in 1643 submitted to Queen Christina a new draft-code of local law "Land Law of the Principality of Livonia" ("Landrecht des Fürstenthums Lieffland"), codified by Baltic German lawyer Engelbrecht von Mengden, for approval. However, Christina postponed approval of draft-code until its evaluation by a special commission, ${ }^{23}$ but in 1648 she allowed provisional using of the Middle Livonian Knightly Law (Mittleres Livländisches Ritterrecht) - an archaic source of Livonian law of early $15^{\text {th }}$ century till new code of law will be compiled and published in Livonia. ${ }^{24}$ The subsequent efforts of Livonian knighthood to obtain approval of Mengden's draft-code from Charles XI also proved unsuccessful.

Apparently, this reluctance of the Swedish government to approve Livonian draft-code was related with different political considerations: to develop a single new codification of law for Sweden, Estonia, Livonia, and Pomerania. A special Legislative Commission was set up in 1694 in Stockholm to carry out this task and began the preparational works, which were suspended after the death of Charles XI in 1697.25

19 Kotkas, T., Royal Police Ordinances in Early Modern Sweden: The Emergence of Voluntaristic Understanding of Law, Brill, Leiden, 2014, pp.117, 163.

20 See original Swedish text of the letter of Swedish king Charles XI of $22^{\text {nd }}$ December 1686 to High Court of Livonia in: Zemzaris, T., Spīdzināšana kā procesa elements Vidzemēe, Tieslietu Ministrijas Vēstnesis, No. 1, 1938, pp. $202-203$.

${ }^{21}$ Pihlajamäki, H., op. cit., p. 263.

22 Geschichtliche Uebersicht der Grundlagen und der Entwickelung des Provinzialrechts in den Ostseegouvernements. Besonderer Theil, pp. 148 - 149; Švābe, A., Latvijas tiesību vēsture. III daḷa, LU stud. Padomes grāmatnīcas izdevums, [Rīga], 1934, pp. 5 - 6.

23 Buddenbrock, G.J. v. (editor), op. cit., p. 183.

24 Ibid., p. 222.

25 Историческія свъденія об основаніях и ходъ мъстнаго законодательства губерній Остзейскихъ, р. 145. 
The last attempt to replace the local laws of Livonia with Swedish laws was taken by Charles XII in time of the Great Northern War by issuing a special document on June 12, 1707, stipulating that henceforth only Swedish laws will be applied in Livonia. But this order could not be carried out because almost all of territory of Livonia had been occupied by Russian troops since $1705 .{ }^{26}$ So, the last attempt of unification of law of Livonian province with law of Sweden was unsuccessful because Sweden lost the war and was forced to hand over Livonia, Estonia and Ingria to the Russian Empire.

\section{Recognition of the privileges of Baltic German upper classes in Baltic governorates by the Russian Empire in $\mathbf{1 8}^{\text {th }}$ century}

The privileges of the Baltic German knighthood (Ritterschaft) and gentry (Landschaft), as well as, upper classes of cities of the Baltic governorates - Estonia and Livonia - were recognised by Russian state in 1710 when territory of these governorates of Sweden was occupied by Russian troops. ${ }^{27}$ On $30^{\text {th }}$ September 1710 Russian tsar Peter I issued a book of grace to the nobility of the Duchy of Livonia (General Confirmation), by which all the privileges of nobility of Livonia were confirmed, among others also The Privilege of Sigismund Augustus (1561) to the knighthood of Livonian Order that was not recognised by the rulers of Poland and Sweden, which ruled after Sigismund II Augustus. However, the text of the General Confirmation contained a reservation that the previous rights of Livonian nobility are recognized "as far as they are in conformity with the present Government and time". ${ }^{28}$ This meant that privilege of Sigismund Augustus was not fully recognized, but as far as it did not contradict to administrative and legal system of Livonia as it was in early $18^{\text {th }}$ century and fundamental laws of Russia. Thus, for example, the landlords of Livonia did not obtain the right to criminal jurisdiction over their serfs, that was given them by The Privilege of Sigismund Augustus, because they had already completely lost the judicial power over their peasants under Swedish rule.

${ }^{26}$ Geschichtliche Uebersicht der Grundlagen und der Entwickelung des Provinzialrechts in den Ostseegouvernements. Allgemeiner Theil, Drukerei der Zweiten Abtheilung S.K.M. Eigener Kanzellei, St. Petersburg, 1845, p. 127.

27 Іюля 4. [1710] Аккордные пункты, заключенные въ лагер подъ Ригой между Шляхетствомъ и Земствомъ Княжества Лифляндскаго и Генераль-Фельдмаршаломъ Графомъ Шереметевымъ. - ПСЗРИ, Собраніе 1-ое. Томъ IV, док. № 2279, pp. 519 - 526; Сентября 29. [1710] Договорные пункты, учиненные въ Главной Квартиръ Гарк близъ Ревеля, между Шляхетствомъ и Земствомъ Герцогства Эстляндскаго и Россійскимъ Генералъ - Поручикомъ Боуеромъ. - ПСЗРИ, Собраніе 1-ое. Томъ IV, док. № 2299, pp. 567 - 575; Іюля 4. [1710] Договорныя статьи, предложенныя депутатами города Риги. - ПСЗРИ, Собраніе 1-ое. Томъ IV, док. № 2278, pp. 515 - 519; Сентября 29. [1710] Договоръ, заключенный въ лагерь подъ Ревелемъ депутатами онаго города съ Россійскимъ Генераль - Поручикомъ Бауеромъ. - ПСЗРИ, Собраніе 1-ое, Томъ IV, док. № 2298, pp. 560 - 567.

28 Сентября 30. [1710] Жалованная грамота дворянству Княжества Лифляндскаго. - ПСЗРИ, Собраніе 1-ое. Томъ IV, док. № 2301, p. 576. 
It should be noted that knighthood of Livonia hoped to obtain from Russian government the right to an autonomous court system with the Supreme Court of Appeal in Riga, where all appeals against judgments of Livonian courts would be finally decided, as it was stipulated in Point VI of The Privilege of Sigismund II Augustus and was basically observed during the time of Polish and Swedish rule. However, under the pretext of financial difficulties at the time, Peter I postponed the implementation of the request until a more appropriate time, which never came. ${ }^{29}$ So, in $18^{\text {th }}$ century Baltic provinces lost judicial autonomy as the highest judicial instance for courts of Baltic governorates became the St. Petersburg Justice College for Livonian, Estonian and Finnish Affairs. ${ }^{30}$

It must be added that in the General Confirmation a majesty clause was also included which declared that the authority and rights of ruler and his states must be observed by all.

On the same date when General Confirmation was issued to Livonian nobility, the city of Riga also received a book of grace from Peter I, in which the Russian tsar confirmed all previously granted privileges, city rights, statutes, municipal positions, freedoms, ancient customs, benefits, justice, inheritable estates and possessions. ${ }^{31} \mathrm{~A}$ similar confirmation of rights and privileges for the knighthood and land gentry of the Estonian province and the burghers of Reval took place in the books of grace issued in March of 1712. ${ }^{32}$

The incorporation of Livonia and Estonia, as well as, Ingria and Karelia into the Russian empire was finalised by the Treaty of Nystad of $1721,{ }^{33}$ which put an end to the Great Northern War. In Treaty of Nystad, Russian government promised that all the inhabitants of Livonia and Estonia, as well as, the inhabitants of Ösel (Saaremaa) island, both noble and non-noble, and the cities, magistrates and craft guilds of these provinces in "the privileges, customs, laws and justice of the Swedish ruling time will be permanently and irrevocably maintained and protected" (Art. 9). In fact, this

29 Октября 12. [1710] РЊшеніе государя Петра I - на представленные въ волю Его Величества, пункты дворянства и жителей Лифляндскихъ, при покореніи ихъ Россійской державђ. - Данное въ Санкт-Петербургъ за подписаніемъ канцлера Графа Головкина. - ПСЗРИ, Собрание 1-ое, Томъ IV, док. № 2304, p. 579.

${ }^{30}$ Bartlett, R., The Russian Nobility and the Baltic German Nobility in the Eighteenth Century, Cahiers du monde russe et soviétique, vol. 34, n¹-2, Janvier-Juin 1993, p. 235; Zeids T., Senākie rakstîtie Latvijas vēstures avoti, Zvaigzne, Rīga, 1992, pp. 173 - 174.

31 Сентября 30. [1710] Жалованная грамота городу Ригъ. - ПСзРИ, Собраніе 1-ое. Томъ IV, док. № 2302 , p. 577.

32 Марта 1. [1712] Жалованная грамота шляхетству и земству Эстляндскаго княжества. - ПСЗРИ, Собраніе 1-ое. Томъ IV, док. № 2495, p. 810; Марта 13. [1712] Жалованная грамота городу Ревелю. - ПСЗРИ, Собраніе 1-ое. Томъ IV, док. № 2501, р. 819.

33 Августа 30. [1721] Трактатъ, заключенный на конгрессъ въ Ништать уполномоченными Министрами, о въчном миръ между обоими Государствами. - ПСЗРИ. Собраніе 1-ое. Томъ VI, док. № 3819, pp. 420 - 431. 
article of the Treaty of Nystad was partly in discrepancy with the confirmation of The Privilege of Sigismund Augustus by Russian tsar in 1710 because it never was recognised by the Swedish government.

There would be an interesting question about motives why the Russian authorities so favourably responded to the demands of the Baltic German elite on issues of preserving the former local administrative system and laws, accepting the local official language as German, instructing the Governing Board of each Baltic governate to establish a special German chancellery for correspondence with local administration institutions and domestic addressees, as well as, Russian chancellery for correspondence with central institutions.

Usually, motives of generosity of conqueror are explained by scholars from aspect of the current considerations of the conquering country in areas of domestic and foreign policy, without touching on more abstract principles laying in the field of legal culture. For example, contemporary Russian legal historians Sergei Kodan and Sergei Fevralev pointed out that "the supreme authority of Russia was well aware that by reaching sympathy of the local elites and, if possible, the majority of the population, will promote the legitimisation of Russian power among the population, it would be able to ensure internal political stability in the national region and the geopolitical stability of the Russian state in relations with neighbouring countries". ${ }^{34}$

In turn, the contemporary German historian of Baltic German origin, Jürgen von Ungern-Sternberg, has noted that not only the current domestic and foreign policy considerations of Russian government must be taken into account, but a special attention must be devoted also to the practice of international law, which had developed in Europe long before the $18^{\text {th }}$ century, regarding the conclusion of agreements on the surrender of a state, land, city, fortress to the enemy. ${ }^{35}$ Comparison of surrender agreements which were concluded between Kingdom of France and city of Strasbourg in 1681, and between Habsburg Empire and Transylvania in 1688 with 1710 capitulation agreements between officials of Tsardom of Russia and representatives of knighthood of Livonian and Estonian governorates allowed J.Ungern-Sternberg to make a conclusion that all these surrender agreements were highly similar in their form and content. The main purpose of these agreements was to guarantee the status quo of the local administrative regulation and local law of the newly acquired territories on the part of the new ruler. For Peter I, as it was pointed out by J.Ungern-Sternberg, "they were an essential part of his strategy to integrate

\footnotetext{
34 Кодан, С.В., Февралёв, С.А., Местное право национальных регионов Российской империи: истоки, место в политике и идеологии, юридическая природа (вторая половина XVII - начало XX вв.). In: Юридические исследования. 2013, № 2, [online]. DOI: 10.7256/2305-9699.2013.2.464 URL: https://nbpublish.com/library read article.php?id=464, c. 74 - 154. Accessed 10 June 2020. 35 Ungerns-Šternbergs, J. fon, Kā notiek kapitulācija? Baltiešu kapitulācijas Pēterim I Eiropas kontekstā, Latvijas Vēsture, No. 4 (48), 2002, pp. 11 - 20.
} 
Russia into the system of European states". ${ }^{36}$

One of the most important points (10. $\S)$ of the surrender agreement of 1710 was the demand of the Livonian knighthood for the codification and ratification of provincial law. As it was noted before, this requirement, which was accepted by The Privilege of Sigismund Augustus in 1561, was implemented neither in the period of the Polish-Lithuanian Commonwealth, nor in the period of Swedish rule in Livonia. How it was noted by English historian Roger Bartlett, codification would have given permanent legal validity to these insecure rights of Livonian knighthood, because their recognition without codification was considered as a personal grant of monarch and the confirmation of these rights was necessary anew each time when a new reign was started. ${ }^{37}$ Upon a request for passing new laws or codification for the province of Livonia, Peter I adopted a resolution stating that the request could be granted when peace-time would be given by God. ${ }^{38}$ The new request for codification of provincial law was sent by Landtag of Livonia to Emperor Peter II, who by resolution of $12^{\text {th }}$ of September 1728 ordered to establish special commission of Livonian knighthood for preparing of new codification of provincial knighthood and land law. ${ }^{39}$ The Codification Commission of 7 members was constituted by Livonian Landtag in 1730, but active codifiers were only two - Vice - President of Dorpat High Court Johann Gustav Budberg and Assessor of this court Johann Schrader. ${ }^{40}$ Their work was completed in 1737 by preparing a new draft-code with a title "Knighthood and Land Laws of the Duchy of Livonia" ("Des Herzogthums Livland Ritter- und Landrechte") which was adopted by Landtag in 1740 and in the next year was sent for final approving in St Petersburg. In 1755 the Russian translation of Budberg - Schrader draft-code was received in Senate and there it was mentioned for the last time in the act of 1764 . At this time Empress Catherine II started to realise a policy of the centralization of administrative system and unification of law in all the Russian Empire and as result there was a loss of interest to Livonian draft-code in the governing circles. ${ }^{41}$ This attempt of $18^{\text {th }}$ century to codify provincial law of Livonia was no more successful as two previous ones in times of Polish and Swedish rule.

The last territory ruled by Baltic Germans - Duchy of Courland was incorporated

36 Ibid., p. 16.

${ }^{37}$ Bartlett, R., op. cit., p. 235.

38 Октября 12. [1710] Ршеніе государя Петра I - на представленные въ волю Его Величества, пункты дворянства и жителей Лифляндскихъ, при покореніи ихъ Россійской державђ. - Данное въ Санкт-Петербургъ за подписаніемъ канцлера Графа Головкина. - ПСЗРИ, Собрание 1-ое, Томъ IV, док. № 2304, p. 579.

39 Сентября 12. [1728] Именный, состоявшійся в Верховномъ Тайномъ Совътъ. - ПСЗРИ, Собрание 1-ое, Томъ VIII, 1728 - 1732, док. № 5330, pp. 89 - 90.

40 Vipers R., Budberga un Šrādera kōdeka projekta izstrādāšana 1730. - 1740.g., Senatne un Māksla, No. 4, 1936, pp. $19-27$.

41 Zeids, T., op. cit., pp. $187-188$. 
into the Russian Empire in context of the Third Partition of Poland (1795) by which neighbouring great powers - Russia, Prussia and Austria liquidated Polish state. Nobility of the Duchy of Courland, troubled by the growing political instability because of uprising in this vassal state supported by T. Kościuszko revolutionary army, decided in a Landtag of the Duchy of Courland convened in late June - early July 1794 to ask Empress Catherine II to take a protectorate over the Duchy, "until Poland will return to order" ${ }^{42}$ In talks with Russian representatives in St. Petersburg, delegates of Landtag had to agree to the liquidation of the status of vassal state for Duchy of Courland by incorporation of its territory directly into the Russian Empire, yet preserving its existing laws and nobility privileges. The duke of Courland, Peter Biron, who arrived in St. Petersburg in February 1795, was also forced to accept these conditions.

On $7^{\text {th }}$ March 1795 the Landtag of the Duchy of Courland in Mitau (now Jelgava) adopted two historical acts - a Manifesto for the Abandonment of the existing ties with Poland ${ }^{43}$ by which the nobility of the Duchy of Courland renounced the Treaty of Subjection of 1561, and the Act of Submission to the rule of the Russian empress Catherine II ${ }^{44}$ by which status of the Courland as a vassal state was renounced and it was directly subjected to Catherine II. After adoption of these acts by Landtag, duke Peter Biron had no other choice but to sign on $17^{\text {th }}$ of March 1795 an abdication from throne of the Duchy of Courland and his rights as duke. ${ }^{45}$

Developments in the District of Pilten (it was earlier territory of former Bishopric of Courland of Livonian Confederation) which was under direct rule of Poland, enjoying local autonomy, were similar. On $17^{\text {th }}$ of March 1795 the Collegium of Landrates of the District of Pilten and representatives of the knights and nobility from the parishes of district gathered in Hasenpoth (now Aizpute in Latvia) for a land conference, which, as before Landtag of the Duchy of Courland, adopted a Manifesto on Abandonment of previous ties with the Polish state. ${ }^{46}$ Immediately after it, the land conference adopted an Act of Submission to Russian Empress Catherine II, stating that a small area had to subject its political existence to a "wise and humane

\footnotetext{
${ }^{42}$ Dunsdorfs, E., Latvijas vēsture. 1710. - 1800. Daugava, [Stockholm], 1973, p. 164.

${ }^{43}$ Manifest einer Wohlgebohren Ritter= und Landschaft der Herzogthümer Curland und Semgallen, über zeitherigen Verbindung mit Pohlen. - ПСЗРИ. Собраніе 1-ое. Томъ XXIII, док. № 17319, pp. $668-672$.

44 Unterwerfungsakte Einer Wohlgebohren Ritter= und Landschaft der Herzogthümer Curland und Semgallen, an Ihro Kayserlichen Majestät. - ПСЗРИ. Собраніе 1-ое. Томъ ХХІІІ, док. № 17319, pp. $672-676$.

45 Akt der Entsagung Sr. Durchlaucht des Herzogs von Curland und Semgallen von den ihm, als regierendem Herzoge daselbst zuständigen Rechten. - ПСЗРИ. Собраніе 1-ое. Томъ XXIII, док. № 17319 , pp. $666-668$.

${ }^{46}$ Manifest der Regierung und Einer sämtlichen Wohlgebohrnen Ritter - und Landschaft des Piltenschen Kreises, über die Entsagung ihrer bisherigen Verbindung mit Pohlen. - ПСЗРИ. Собраніе 1-ое. Томъ XXIII, док. № 17319, pp. 676 - 683.
} 
arrangement of strong monarchs". ${ }^{47}$

In response to declarations made by the Landtag of Duchy of Courland and the land conference of the District of Pilten attained by Russian political pressure, Catherine II on $15^{\text {th }}$ of April 1795 published a book of grace promising not only the freedom of religion, preserving existing law, privileges, respect for lawfully owned property, but also the granting of the rights and freedoms enjoyed by Russian subjects. ${ }^{48}$

Unlike the provinces of Livonia and Estonia, the Duchy of Courland as vassal state adopted in $16^{\text {th }}-17^{\text {th }}$ centuries several important acts of legislation in both public and private law. The first of these was The Privilege of Gotthard (Privilegium Gothardinum, 1570), ${ }^{49}$ issued to the Duchy's nobility by the first Duke Gotthard Kettler. It received the confirmation of King of Poland-Lithuania Stephen Báthory in $1581 .^{50}$ The Privilege of Gotthard largely took over the rules of the Privilege of Sigismund Augustus. However, the guarantees given to a person in The Privilege of Gotthard were extended, because this act stipulated not only the inviolability of property, but also the inviolability of the person. The subjects had guaranteed the right to complain to the court about illegal actions of administrative authorities. The King of Poland, who was to assume the function of constitutional supervision, was mentioned as a guarantor of the constitutional rights of the subjects of the Duchy of Courland. Privilege also confirmed full supreme and lower judicial authority of nobility over their peasants, including the grave crimes, as it was earlier approved by the Privilege of Sigismund Augustus.

In 1611, after the approval of King Sigismund III of Poland, The Laws and Statutes of the District of Pilten ("Gesetze und Statute des Piltenschen Kreise"), codified by the local nobleman Carl von Sacken in German came into force. This fact provoked complaints from the nobility of the Duchy of Courland to the King of Poland that the promise given in the Privilege of Gotthard to codify the laws of duchy had not yet been fulfilled. In response to these complaints, Sigismund III sent in 1617 a commission led by Bishop of Kulm Jan Kuczborski. The commission

\footnotetext{
${ }^{47}$ Unterwerfungsakte der Regierung und einer sämtlichen Wohlgebohrnen Ritter- und Landschaft des Piltenschen Kreises, an Ihro Kayserlichen Majestät. - ПСЗРИ. Собраніе 1-ое. Томъ ХХІІІ, док. № 17319 , pp. $683-685$.

48 Апрьля 20. [1795] Именный, данный Сенату. О присоединении на вчныя времена къ Россійской Имперіи Княжествъ Курляндскаго и Семигальскаго, также округа Пильтенскаго и о приглашеніи уполномоченныхъ въ Сенатъ для учиненія присяги на вьрность подданства. - ПСЗРИ. Собраніе 1-ое. Томъ XXIII, док. № 17319, pp. $664-666$.

${ }^{49}$ See German text of the Privilege of Gotthard in: Ziegenhorn, Ch. G., op. cit., No. 76, pp.85 - 88.

${ }^{50}$ See original text of Confirmation in: LVVA (Latvian State Historical Archives), Collection 554, Inventory 1, File 33.

${ }^{51}$ See German text of codification of The Laws and Statutes of the District of Pilten in: Rummel, C. von., Die Quellen des Curländischen Landrechts. Bd. I, Lief. 4, F. Kluge, Dorpat, 1850, pp. 1 - 93.
} 
prepared two draft laws - the Formula of Government ("Formula Regiminis in Ducatu Culandiae et Semigalliae") ${ }^{52}$ and the Statutes of Courland ("Statuta Curlandica"). ${ }^{53}$ The Formula of Government was the first written constitution which was in effect in territory of Latvia and, consequently, it was one of the oldest European constitutions. The Statutes of Courland was a code of procedure, civil and criminal law of the Duchy of Courland which was not approved by king of Poland, because of hostilities of that period, but it was used by the courts of the Duchy of Courland and later was recognised also by Polish government. ${ }^{54}$

\section{The attempt towards liquidation of the legal autonomy of Baltic governorates in the reign of Catherine II}

For the most part of the $18^{\text {th }}$ century the administrative privileges of Baltic German knighthood in Livonian and Estonian governorates were observed by Russian authority (German was accepted as official language in both governorates, previous courts and their litigation procedures were recognised, as well as, applying of the former knighthood and land law, urban law in cities, and Roman pandect law as subsidiary law in legal disputes was continued).

However, in the eighties of $18^{\text {th }}$ century storm clouds brooded in the Baltic governorates over knighthood representative institutions - landtags, which had limited rights of legislation - to prepare and adopt local draft-laws which had to be approved by monarch of the Russian Empire to come in effect. The first serious step on unification was made by Empress Catherine II applying the reform of the Russian territorial administrative system of $1775^{55}$ to the governorates of Estonia and Livonia which were renamed by her decrees of 1783 as Reval and Riga governorates. ${ }^{56}$ There was introduced administrative regime of so-called vicegerency (наместничество) in these governorates, as well as, in the newly established governorate of Courland in $1796 . .^{57}$

\footnotetext{
${ }^{52}$ See Latin text of Formula Regiminis in: Rummel, C. von., Die Quellen des Curländischen Landrechts. Bd. I. Lief. 3. Acta Commissionis de anno 1617. F.Kluge, Dorpat, 1848, pp. 19 - 37.

53 See Latin text of Statuta Curlandica in: Ibid., pp. 43 - 92.

54 Geschichtliche Uebersicht der Grundlagen und der Entwickelung des Provinzialrechts in den Ostseegouvernements. Allgemeiner Theil, p. 161.

55 Учрежденія для управленія Губерній Всероссійскія Имперіи. - ПСЗРИ. Собраніе 1-ое. Томъ ХХ, 1775 - 1780, док. № 14392, с. 231 - 232.

56 Іюля 3. [1783] Именный, данный Сенату. - Объ учрежденіи Ревельской Губерніи изъ пяти округовъ или уъздовъ. - ПСЗРИ. Собраніе 1-ое. 1649 - 1825 гг. Томъ ХХІ. Съ 1781 по 1783, док. № 15774, с. 967; Іюля 3. [1783] Именный, данный Сенату. - Объ учрежденіи Рижской Губерніи изъ девяти округовъ или уъздовъ. - ПСЗРИ. Собраніе 1-ое. 1649 - 1825 гг. Томъ ХХІ. Съ 1781 по 1783, док. № 15775 , с. 967.

57 Ноября 27. [1796] Именный, данный Сенату. - О составленіи Курляндской Губерніи изъ девяти уъздовъ. - ПСЗРИ. Собраніе 1-ое. 1649 - 1825 гг. Томъ XXIII. Съ 1789 по 6 ноября 1796, док. № 17410 , c. 818 .
} 
Catherine II had intended to create a uniformed social estate of nobility throughout Russia eliminating in this way Baltic German knighthood as a special estate in the Baltic governorates along with its special representative institutions. On $21^{\text {st }}$ of April 1785 Catherine II granted the Russian nobility a book of rights, freedoms, and privileges, ${ }^{58}$ which established a unified legal framework for nobility and their organisations in all the Russian Empire. By regulations of this book, the nobles could meet at the nobility meetings of governorate every three years on the initiative and permission of the Governor-General or Governor. The landtags of Riga and Reval governorates were abolished, since henceforth all the nobles had the equal right to participate in the nobility meetings, whether they belonged to the Baltic German knighthood or not. The nobility meeting nominated two candidates for the position of governorate nobility leader, one of whom was appointed by the GovernorGeneral or Governor for a term of three years. The nobility meetings were conferred the right to respond to proposals by the Governor-General or Governor, to petition the Governor-General or Governor for public needs, to complain to the Senate, and to the Emperor. Unlike landtags, no legislative power was conferred to the nobility meetings. By the decree of $12^{\text {th }}$ August 1786, Catherine II also liquidated collegia of landrats (executive bodies of landtags) in the Riga and Reval governorates, forcing to hand over the estates, which provided funding for the activities of collegia of landrats, to the crown chambers of these governorates. ${ }^{59}$ As a result, the political position of the Baltic German knighthood was seriously undermined and the legislative and administrative autonomy of the Baltic provinces was abolished. Radical reform of limited self-government was also implemented by Catherine II in the cities and towns of Baltic governorates, by which a unified administrative arrangement for all the cities of the Russian Empire was established. ${ }^{60}$

American scholar of political science Nicklaus Laverty has characterized policy of Catherine II in Baltic governorates as "mild administrative Russification", pointing out that "the object of Catherine's reforms was to harmonize peripheral territories into the administrative structure of the empire, while still leaving most cultural rights and privileges (such as religion or language) untouched", ${ }^{61}$ but Estonian historian

\footnotetext{
58 Апрњля 21. [1785] Грамота на права, вольности и преимущества благороднаго Россійскаго дворянства. - ПСЗРИ. Собраніе 1-ое. Томъ ХХІІ. Съ 1784 по 1788, док. № 16187, с. 344 - 358.

59 Августа 12. [1786] Именный, данный Сенату. - О небытіи въ Рижской и Ревельской губерніяхъ Ландратамъ и Ландратскимъ Коллегіямъ и о принятіи въ въдомство Казенныхъ Палатъ деревень, с коихъ доходы собирались на содержаніе Ландратовъ. - ПСЗРИ. Собраніе 1-ое. Томъ ХХІІ, Съ 1784 по 1788, док. № 16424, с. 671 - 672.

60 Апрьля 21. [1785] Грамота на права и выгоды городамъ Россійской имперіи. - ПСЗРИ. Собраніе 1-ое. Томъ XXII, док. № 16188, с. 358 - 384 .

61 Laverty, N., Imperial Janus: Patterns of Governance in the Western Borderlands of the
}

Tsarist Empire. (2014). Doctoral Dissertations. 148, p.177-178. - https://scholarworks.umass.edu/ dissertations_2/148. Accessed 5 June 2020. 
Mati Laur noted that "as a result of the reforms attempted by Catherine II society in the Baltics began to change gradually; instead of society ruled by upper classes a society of integrated citizens subjected to the government of absolute state power started to develop". ${ }^{62}$

Catherine II also had a far-reaching plan to establish a unified system of new law for all territories of the Russian state based on principles of natural law and she was very disappointed that representatives of Baltic governorates in Legislative Commission of 1767 defended the retaining of the existing local law for Baltic governorates. ${ }^{63}$ But her design was unsuccessful because of the contradictions of the members of the Legislative Commission, many of whom were not ready to accept the ideas of the Enlightenment as personal liberty, legal equality etc., as well as, the lack of proper legal qualifications for many of them.

So, for a comparatively short period the trend of unification began to prevail in Baltic governorates. After death of Catherine II in 1796 her son - Emperor Paul abolished her reforms and restored administrative system of Baltic governorates in main features as it was before $1785^{64}$ renewing also the historical names of the Livonian and Estonian governorates. ${ }^{65}$ Thus Paul sought to emphasize the inviolability of the traditional rights which the Russian rulers had undertaken to guarantee. Thereby, the administrative and legal autonomy of the Baltic provinces was maintained for more than a century, though with the political dominance of the Baltic German elite over the indigenous peoples - Latvians and Estonians.

\section{Evolution of local law of Baltic governorates in $19^{\text {th }}$ century - reforms, codification, and growing unification trend}

The situation in the legal system of the Baltic provinces in $19^{\text {th }}$ century maybe characterized as a growing discrepancy between the obligation of Russian state to maintain the legal framework of Baltic governorates as it was in times of Swedish rule or Duchy of Courland and necessity to take in account new public needs and

${ }^{62}$ Laurs, M., Katrīna II un muižniecības autonomija Baltijā, Latvijas Vēstures Institūta Žurnāls, No. 3, 2013, p. 44.

${ }^{63}$ Ibid., p. $36-37$.

${ }^{64}$ Ноября 28. [1796] Именный, данный Сенату. - О возстановленіи въ Лифляндіи и Эстляндіи Присутственныхъ мЂстъ, кои по тамошнимъ правамъ и привиллегіямъ существовали до 1783 года. ПСЗРИ. Собраніе 1-ое. Томъ XXIV. Съ 6 ноября 1796 по 1798, док. № 17584, с. 20 - 21; Декабря 24. Именный, данный Сенату. - О возстановленіи въ Курляндской Губерніи Присутственныхъ мъстъ, существовавшихъ по прежнимъ правамъ и привиллегіямъ до открытія Намстничества. ПСЗРИ. Собраніе 1-ое. Томъ XXIV. Съ 6 ноября 1796 по 1798, док. № 17681, с. 251.

65 Декабря 12. [1796] Именный, данный Сенату. - О новом раздъленіи Государства на губерніи. - ПСЗРИ. Собраніе 1-ое. 1649 - 1825 гг. Томъ XXIV. Съ 6 ноября 1796 по 1798, док. № 17634, с. $229-230$. 
changes in social ideology and relations which no longer corresponded to old legal framework. There were two possible options to solve this conflict of old law with new reality: (1) to adopt special new laws for Baltic governorates taking in account the specific features of social relations and local legal traditions; (2) to apply modern laws of the Russian Empire also at Baltic governorates, including, if it would be necessary, special local rules in them. It should be noted that both these methods were used during $19^{\text {th }}$ century: until the seventies the method of adopting of new local laws prevailed, but later the Russian government began to extend the application of new Russian laws to the Baltic governorates.

The significant example of using of the first method was preparing and adopting the peasantry laws of Baltic governorates by which the peasants were emancipated from yoke of serfdom (on 1816 in Estonia, 1817 in Courland and 1819 in Livonia) i.e. more than forty years before serfdom was abolished in Russian governorates. The laws on the liberation of peasants of the Baltic governorates were apparently a pilot project of Alexander I before preparing the corresponding law for the Russian governorates. But these laws were worked out by the special legislative commissions established for any Baltic governorate. The draft-laws then were adopted by landtag of the respective governorate and after translation of their texts from German into Russian they were approved by emperor Alexander I, acquiring the force of local law applied in territory of the respective governorate. ${ }^{66}$

The main contribution of the following rulers of the Russian Empire - Nicholas I and Alexander II in the development of Baltic law was codification of Local Laws of Baltic governorates (LLBG) ${ }^{67}$ so ensuring their easier and more effective applying in the administrative bodies and the courts. LLBG was the only example of codification of local law in the Russian Empire. This code consisted of three parts (Part 1 "Institutions" (1845), Part 2 "Laws of Estates" (1845), Part 3 "Civil Laws" (1864)) which were codified by the method of consolidation of the previous laws and legal customs of different epochs which were in effect from $12^{\text {th }}$ century till moment of codification at territory of Baltic governorates, especially, Roman law which was recognised as subsidiary law by Baltic German lawyers. This method of codification was based on theory of the German Historical School of Jurisprudence which was accepted by Nicholas I. The codifier of Part 1 and 2 was a Vice-President of the High Court (Hofgericht) of Livonian governorate Reinhold Samson von Himmelstiern, but of Part 3 - former professor of legal history of Dorpat (now Tartu) University and

\footnotetext{
${ }^{66}$ See further: Blūzma V., Legal Regulation of the Abolition of Serfdom in Baltic Governorates of the Russian Empire in Early 19 $9^{\text {th }}$ Century: Historical Background, Realisation, Specific Features and Effect. In: Social Changes in the Global World. $6^{\text {th }}$ International Scientific Conference. Proceedings. Shtip, 2019 , pp. $575-588$.

${ }^{67}$ Сводъ мъстныхъ узаконеній губерній Остзейскихъ. Часть первая. Учрежденія. СанктПетербург, 1845; Сводъ мъстныхъ узаконеній губерній Остзейскихъ. Часть вторая. Законы о состояніяхъ. СанктПетербург, 1845; Сводъ мъстныхъ узаконеній губерній Остзейскихъ. Часть третія. Законы гражданскіе. СанктПетербург, 1864.
} 
syndic (legal adviser) of Reval Friedrich Georg von Bunge. It was planned also to codify Part 4 (Civil Procedure Law) and Part 5 (Criminal Procedure Law) ${ }^{68}$ but as Russian Judicial Statutes of 1864 came into effect at Baltic governorates in 1889 the codification works of these parts were discontinued. ${ }^{69}$

Unlike the peasantry laws, LLBG was a single codification for all three Baltic governorates. But along with the common rules which were in effect in all Baltic governorates, it also contained the rules applied in one or another governorate, in territories of cities or in land areas of any governorate. The special rules for different privileged estates also were included in this code. The codifiers had no rights to add any new rules, they had to make references to historical sources for every article of this codification. Civil law of Part 3 was applied only by the nobility, clergy, and citizens, but peasants had to apply civil law as it was regulated in the codes of peasantry laws, but civil law rules of LLBG might be applied by them as subsidiary source only. So, characteristic feature of LLBG was the territorial and estate particularism of law. The analysis of references on sources of articles for Part 3 allows researchers to make a conclusion that $63 \%$ of all the articles (2882 from 4600) were based directly or indirectly on Roman law. ${ }^{70}$

In the end of sixties of $19^{\text {th }}$ century, prominent Russian Slavophile Yury Samarin began a discussion against the opinion of the Baltic German authors that the capitulation acts of Baltic German nobility and burghers to Russia of 1710 were international treaties between the privileged estates of the Baltic provinces and ruler of Russian state. He argued that the Baltic knighthood and burghers were not persons of international law and when they came under power of Russian state, they could no longer be in a treaty relationship with Russian emperor. Therefore, the acts of capitulation of 1710 should be regarded as books of grace only, the legal force of which depended on the will of the Russian emperor. ${ }^{71}$ Pointing to fact that the privileges of the Baltic German elite are now codified in LLBG, and the autocratic power is the only source of general and local laws of the Russian Empire, Y.Samarin questioned the possibility of preserving the privileges of the Baltic German elite in future, noting with good reason that "throughout the whole world the road of historical progress is littered with fragments of privileges and in this respect even the Baltic region is no exception." ${ }^{72}$ In defence of the historical privileges of the Baltic Germans, Carl Shirren, a professor of Russian history of the University of Dorpat, replied to Y.Samarin by pamphlet trying to challenge his theses and declaring that "the German nation and its descendants in these lands and these lands for the

\footnotetext{
${ }^{68}$ See Art. 3 of Part 1 of LLBG.

${ }^{69}$ See also: Лутс-Соотак М., Гражданское уложение Остзейских губерний (1864/65) как памятник римского права, Вестник НГУ. Серия: Право. 2012. Том 8. Выпуск 2, pp. 262 - 273.

${ }^{70}$ Kalniņš, V., op. cit., p. 304.

${ }^{71}$ Самарин, Ю. Ф., Окраины Россіи. Серія первая. Русское Балтійское поморіе. Выпускъ I, Прага, 1868 , pp. $165-183$.

72 Ibid., p. 183.
} 
German nation and its descendants, that is the sum of all capitulation". ${ }^{73}$ After this publication in which he asked Russian government to stop the trend of unification and russification in Baltic governorates, he had been dismissed from professor post and was forced to emigrate to Germany.

In the second half of $19^{\text {th }}$ century policy of protecting of local autonomy of Baltic governorates and developing of local law was changed by Russian government to policy of gradual unification of Baltic governorates into single administrative and legal system of the Russian Empire. The applying of the modern Russian laws in the Baltic governorates was started from the Russian Criminal code of $1845^{74}$ which came in effect in May 1846 in Baltic governorates as in the other territories of Russia repealing the previous local criminal laws of Baltics.

In its fighting against Baltic German efforts to protect their privileges and local autonomy of Baltic governorates Russian government based on the majesty clause. So, answering on memorandum by which Landtag of Livonia objected to decision of Committee of Ministers of 1850 on replacing German by Russian as official language in crown institutions of Baltic governorates, ${ }^{75}$ Russian emperor Alexander II in the resolution of $28^{\text {th }}$ February 1870 , prepared by himself, stated that "since general and local laws gain power from the authority of the sovereign power only, the request of Livonian knighthood must be rejected (..)" ${ }^{76}$

In 1877 previous local urban laws of Baltic governorates were abolished replacing them by unified Municipal Statute of the Russian Empire (1870). ${ }^{77}$ In result administrative functions were transferred from medieval patriciate body - City Council (Rat) to new institution - City Duma which members were elected every three years and represented the broader circles of the wealthy classes.

Unification policy became highly active in reign of emperor Alexander III. It was a first precedent when Russian emperor ascending the throne did not confirm the protection of the rights of Baltic privileged estates, but formally it might be explained by fact that they were already codified in LLBG as local laws. In reign of Alexander III applying of the Russian Judicial Statutes of 1864 was extended to the Baltic governorates $(1889)^{78}$ with some changes in rules (for example, institute of jury was

73 Schirren, C., Livländische Antwort an Herrn Juri Samarin. 3.Auflage, Duncker \& Humblot, Leipzig, 1869, p. 194.

74 Уложеніе о наказаніяхъ уголовныхъ и исправительныхъ. Санкт-Петербург, 1845.

75 Января 3 [1850]. Высочайше утвержденное положеніе Комитета Министровъ, распубликованное

7 Марта. - О введеніи въ коронныхъ присутственныхъ мъстахъ Остзейскихъ губерній дълопроизводства на Русскомъ языкъ. - ПСЗРИ, Собрание 2-ое, т. XXV, Отд. 1, док. № 23796, pp. 5 - 6.

76 Citation from: Švābe, A., Latvijas vēsture 1800 - 1914. 1, Avots, Rīga, 1991, p. 352.

77 Марта 26 [1877]. Высочайше утвержденныя Правила о примнении высочайше утвержденнаго,

16 Іюня 1870 года, Городоваго Положенія къ городамъ Прибалтійскихъ губерній. - ПСЗРИ, Собрание 2-ое, т. LII, Отд. 1, док. № 57101, pp. $262-266$.

78 Іюля 9. [1889]. Высочайше утвержденныя Положенія о преобразованіи судебной части въ 
not implemented in criminal procedure of Baltic governorates). The former system of courts in Baltic governorates was liquidated and Russian was established as official language not only for the administrative system of the Baltic provinces but also for the proceedings of courts.

Russification of public life in Baltics manifested itself particularly in sphere of education after adoption on $10^{\text {th }}$ of April 1887 Regulation of Committee of Ministers on replacing of German to Russian as teaching language in all the schools of secondary education financed from state budget in Dorpat educational region (included all three Baltic governorates) from $1887 / 8$ school year. ${ }^{79}$ Later in the same way teaching language from German to Russian was changed also in University of Dorpat, but German professors, which were not ready to read lectures in Russian, were replaced by Russian ones. ${ }^{80}$ Russian historian of pedagogy Mikhail Goncharov explained policy of russification in sphere of education in the last decades of $19^{\text {th }}$ century by factors of foreign policy (changing the orientation of Russia from Germany to France and necessity to oppress pro-German orientation of Baltic German privileged minority in Baltic governorates), as well as, factors of home policy (strengthening of ties between central power and western borderlands). ${ }^{81}$ Police reform of 1888 in Baltic governorates also reflected the unification trend.

At the beginning of 20th century no significant legal reforms were carried out in the Baltic governorates. It should be mentioned, however, that during the 1905 revolution, it was declared in the decree on the establishing of the interim Baltic Governorate-General that there is a need to work out a draft-law on the introducing of Zemstvos (local self-government institutions on the model of such bodies in the Russian governorates) in the Baltic governorates ${ }^{82}$ but in practice this declaration was not realised, because competence of zemstvos was more narrow than that which was recognised for landtags in sphere of legislation and Baltic German knighthood was active in defence of their rights.

During the preparation of the draft Civil Code of the Russian Empire (the work was completed in 1905, but the draft-code never entered into force), some Russian lawyers expressed the opinion that its effect should be extended to the territory where local civil law was applicable, particularly in Baltic governorates and Tsardom of Прибалтийскихъ губерніяхъ. - ПСЗРИ, Собрание 3-е, т. IX, док. № 6188, pp. 411 - 449.

79 Апрьля 10 [1887]. Высочайше утвержденное положение Комитета Министровъ. О введеніи преподаванія на Русскомъ языке въ правительственныхъ среднихъ учебныхъ заведеніяхъ Дерптскаго учебнаго округа. - ПСЗРИ, Собраніе 3-е, т. VII, док. № 4343, pp. 152 - 153; Krūze, A., Zigmunde, A., Izglìtības un pedagogiskās domas attīstība Latvijāa. - In: Latvija un latvieši. IV sēj, Latvijas Zinātṇu Akadēmija, Rīga, 2013, p. 103.

80 Гончаров, М., Национально-образовательная политика на западных окраинах Российской империи ХIX-начала XX вв., The Humanities and Social Science, No. 25, 2015, pp. 84 - 85.

81 Ibid., p.84.

82 Ноября 28 [1905]. Именной Высочайшій указъ, данный Сенату. Объ учрежденіи временнаго Прибалтійскаго генераль-губернаторства. - ПСЗРИ, Собраніе 3-е, т. XXV, Отд. 1, док. № 26973, pp. $844-845$. 
Poland. So, Professor Alexei Gulyaev called for an immediate unification of civil law, stating that "there is no reason to postpone the complete merger of local laws with the common civil laws of the Empire." ${ }^{83}$ In turn, the first Latvian legal historian Kărlis Ducmanis cautiously assessed the proposal to replace the Baltic civil law with the Russian civil law, pointing out how "this issue will be resolved in practice, it is difficult to judge in our days, which are so rich in any unexpected contingencies ". ${ }^{84}$ The outcome of World War I for Russia was that unexpected contingency which led to the revolution and collapse of the Russian Empire, the liquidation of the estate system and the emergence of national states - Latvia and Estonia - in the place of the Baltic governorates.

\section{Some conclusions}

The comparison of legal policy of the Polish - Lithuanian Commonwealth, the Kingdom of Sweden and the Russian Empire in Baltic provinces facilitate the better understanding of the common features and differences of legal policies implemented by these states in Baltic region. Despite the differences in the structure and political system of all three states, their political efforts were clearly shifting in the course of time from a policy of respect for the previous law of the newly annexed Baltic provinces to a policy of unification of law by gradual replacing of local law by law of metropolitan state. In turn, the Baltic German political elite of the Baltic provinces had used every opportunity to curb the restriction of local autonomy and local law area, using both domestic political diplomacy methods and foreign policy factors, and has been able to protect limited local autonomy from the $16^{\text {th }}$ century to the beginning of $20^{\text {th }}$ century.

Only the Polish-Lithuanian Commonwealth was able to achieve full unification of law in the Inflanty Voivodeship (Polish Livonia), establishing here the laws of the Grand Duchy of Lithuania in effect from 1677 (after including the territory of Inflanty into the Russian Empire (1772), the laws of inner Russia came into force here from 1831) ${ }^{85}$ In turn, the efforts of the Kingdom of Sweden and the Russian Empire to achieve full unification of the law of the Baltic provinces with metropolitan law were not successful, because active resistance of Baltic German elite and changes of the balance of powers in region.

The autonomy of local law of nationally unique regions could not be sustained for a long time in a centralised absolute monarchy. Russian rulers acknowledged the

\footnotetext{
${ }^{83}$ Гуляевъ, А. М., Единство гражданскаго права и проекть гражданскаго уложенія, Кіевъ, 1903, p. 140.

${ }^{84}$ Ducmanis, K., Iz Baltijas provinču tiesībām, P.Bērziṇš, Rīga, 1913, p. 77.

85 Января 1, [1831] Именный, данный Сенату. О введеніи въ Губерніяхъ: Могилевской и
} Витебской, какъ по Правительственной, такъ и по Судебной части, того самого порядка, который наблюдается во внутреннихъ Областяхъ государства. - ПСЗРИ, Собраніе 2-ое, T. VI, Отд. 1-ое, док. № 4233, p. 1. 
former laws of the Baltic governorates in epoch when Russian administrative and legal culture was on the low level, lagging Western European countries. From the beginning of $19^{\text {th }}$ century it became clear that Baltic governorates had an acute need for legal reforms for transition from medieval system of social estates to bourgeois society of modern times, but the Baltic governorates could not improve their local legal systems without the approval of Russia's central power.

The crucial factor for evolution of Baltic law in $18^{\text {th }}-19^{\text {th }}$ century was a will of Russian emperor. The recognising of previous local law in the newly incorporated territories was interpreted as expressing of the free will of emperor, thus denying any constitutional guarantee of preserving the autonomy of local law should the will of the Russian ruler be changed later. Basing on the majesty clause the central Russian authority in the second half of $19^{\text {th }}$ century proceeded to policy of unification of the administrative and legal system of the Baltic governorates with that in Russian governorates. In itself, the process of unification of rights, as a result of which the modern laws of the Russian Empire replaced the archaic laws of the Baltic provinces, thus ensuring the evolution of law in accordance with the development needs of society, can be seen mainly as a positive process, although it had also the aspects assessed critically as Russification of judicial procedure. ${ }^{86}$

The interests of Baltic German elite to preserve its privileges and positions in the system of local administration had considerable, especially, taking in account the strong influence of Baltic German nobility on the central power, but, however, a secondary role. It is necessary to note that Baltic Germans were minority in population of Baltic region and their positions as elite were weakened in $19^{\text {th }}$ century in acute political struggle with newly formed Baltic nations - Latvians and Estonians. Baltic German elite was not ready to look for compromises with Latvians and Estonians and was strong opponent of all reforms which would diminish its privileges and extend the rights of native peoples of Baltic region.

The establishment of new independent national states - Estonia and Latvia in territory of Baltic governorates in 1918 after collapse of the Russian Empire and defeating of Germany in World War I gave a chance to preserve the Baltic heritage of legal culture and its further development, for example, by codification of Civil Law of Latvia (in effect from 1st January of 1938) which finally liquidated previous territorial and estate particularism of civil law.

\title{
Bibliography
}

\author{
1. Bartlett, R., The Russian Nobility and the Baltic German Nobility in the \\ ${ }^{86}$ See: Luts, M., The Ambivalence of Reforms and their Absence: Baltic Lections of the 19th Century, \\ Juridica International, No. 1, 2006, pp. $73-74$.
}


Eighteenth Century, Cahiers du monde russe et soviétique, vol. 34, n¹-2, Janvier-Juin 1993, pp. $233-243$.

2. Blūzma, V., Legal Regulation of the Abolition of Serfdom in Baltic Governorates of the Russian Empire in Early $19^{\text {th }}$ Century: Historical Background, Realisation, Specific Features and Effect. In: Social Changes in the Global World. $6^{\text {th }}$ International Scientific Conference. Proceedings. Shtip, 2019, pp. 575 - 588.

3. Buddenbrock, G.J. v. (editor), Sammlung der Gesetze, welche das heutige Livländische Landrecht enthalten, kritisch bearbeitet. Bd. II. Aeltere hinzugekommene Landesrechte, Abt. I, Landesordnungen vom Jahr 1621 bis 1680, Häcker, Riga, 1821.

4. Bunge, F.G. v., Einleitung in die liv-, esth- und curländische Rechtsgeschichte und Geschichte der Rechtsquellen, F.J.Koppelson, Reval, 1849.

5. Das Schwedische Land- und Stadt-Recht, G.M. Nöller, Riga, 1709.

6. Dogiel, M., Codex Diplomaticus Regni Poloniae et Magni Ducatus Lituaniae, Tomus V, Vilnae, MDCCLIX.

7. Ducmanis, K., Iz Baltijas provinču tiesībām, P.Bērziņš, Rīga, 1913.

8. Dunsdorfs, E., Latvijas vēsture. 1710. - 1800. Daugava, [Stockholm], 1973.

9. Geschichtliche Uebersicht der Grundlagen und der Entwickelung des Provinzialrechts in den Ostseegouvernements. Allgemeiner Theil, Drukerei der Zweiten Abtheilung S.K.M. Eigener Kanzellei, St. Petersburg, 1845.

10. Geschichtliche Uebersicht der Grundlagen und der Entwickelung des Provinzialrechts in den Ostseegouvernements. Besonderer Theil, Drukerei der Zweiten Abtheilung S.K.M. Eigener Kanzellei, St. Petersburg, 1845.

11. Kalniņš, V., Latvijas PSR valsts un tiesību vēsture. I, Zvaigzne, Rīga, 1972.

12. Kotkas, T., Royal Police Ordinances in Early Modern Sweden: The Emergence of Voluntaristic Understanding of Law, Brill, Leiden, 2014.

13. Krūze, A., Zigmunde, A., Izglìtības un pedagogiskās domas attīstība Latvijā, Latvija un latvieši, IV sēj., Latvijas Zinātņu Akadēmija, Rīga, 2013, pp. 90 119.

14. Laurs, M., Katrīna II un muižniecības autonomija Baltijā, Latvijas Vēstures Institūta Žurnāls, No. 3, 2013, p. 31 - 44.

15. Laverty, N., Imperial Janus: Patterns of Governance in the Western Borderlands of the Tsarist Empire, (2014), Doctoral Dissertations, 148. - https://scholarworks. umass.edu/dissertations_2/148.

16. Luts, M., Private Law of the Baltic Provinces as a Patriotic Act, Juridica International, No. 1, 2000, pp. 157 - 167.

17. Luts, M., The Ambivalence of Reforms and their Absence: Baltic Lections of the 19th Century, Juridica International, No. 1, 2006, pp. 68 -75.

18. Pihlajamäki, H., Conquest and the Law in Swedish Livonia (ca. 1630-1710): A Case of Legal Pluralism in Early Modern Europe, Brill, Leiden, 2017. 
19. Ramm - Helmsing, H., David Hilchen. 1561 - 1610. Syndikus der Stadt Riga, Deutsche Wissenschaftliche Zeitschrift für Posen. Heft 31, 1936, pp. $141-212$.

20. Rummel, C. von., Die Quellen des Curländischen Landrechts. Bd. I. Lief. 3. Acta Commissionis de anno 1617. F.Kluge, Dorpat, 1848.

21. Rummel, C. von., Die Quellen des Curländischen Landrechts. Bd. I, Lief. 4, F. Kluge, Dorpat, 1850.

22. Rusovs, B., Livonijas kronika, Aka, Grand Haven, 1976.

23. Russow, B., Chronica der Prowintz Lyfflandt, Bart, s.l., 1584.

24. Schirren, C., Livländische Antwort an Herrn Juri Samarin. 3.Auflage, Duncker \& Humblot, Leipzig, 1869.

25. Švābe, A., Latvijas tiesību vēsture. III daḷa, LU stud. Padomes grāmatnīcas izdevums, [Rīga], 1934.

26. Švābe, A., Latvijas vēsture 1800 - 1914. 1, Avots, Rīga, 1991.

27. Ungerns-Šternbergs, J. fon, Kā notiek kapitulācija? Baltiešu kapitulācijas Pēterim I Eiropas kontekstā, Latvijas Vēsture, No. 4 (48), 2002, pp. 11 - 20.

28. Vipers, R., Budberga un Šrādera kōdeka projekta izstrādāšana 1730. - 1740.g., Senatne un Māksla, No. 4, 1936, pp. 19 -27.

29. Volumina Legum. Przedruk zbioru praw staraniem XX. pijarów w Warszawie, od roku 1732 do roku 1782, wydanego. T. II, IV, V. J. Ohryzko, Petersburg, 1859 - 1860 .

30. Zeids T., Senākie rakstītie Latvijas vēstures avoti, Zvaigzne, Rīga, 1992.

31. Zemzaris, T., Spīdzināšana kā procesa elements Vidzemēe, Tieslietu Ministrijas Vēstnesis, No. 1, 1938, pp. 155 - 205.

32. Ziegenhorn von, Ch., Staatsrecht der Herzogthümer Curland und Semigallen, J.J.Kanter, Königsberg, 1772.

33. Гончаров, М. Национально-образовательная политика на западных окраинах Российской империи XIX - начала XX вв., The Humanities and Social Science, No. 25, 2015, pp. $79-89$.

34. Гуляевъ, А. М., Единство гражданскаго права и проектъ гражданскаго уложенія, Кіевъ, 1903.

35. Евстратьев, О. Курляндское герияогство в политической системе Речи Посполитой (вторая половина XVI - конец XVIII вв.), Беларускі гысторічны зборнік, No. 47, 2017, pp. $44-56$.

36. Историческія свъденія об основаніях и ходъ мгстнаго законодательства губерній Остзейскихъ, Санктпетербургъ, 1845.

37. Кодан, С.В., Февралёв, С.А., Местное право нацииональных регионов Российской империи: истоки, место в политике и идеологии, юридическая природа (вторая половина XVII - начало XX вв.), Юридические исследования, 2013, № 2, [online]. DOI: 10.7256/2305-9699.2013.2.464 URL: https://nbpublish.com/library read article.php?id=464, pp. $74-154$.

38. Лутс-Соотак, М., Гражданское уложение Остзейских губерний (1864/65) 
как памятник римского права, Вестник НГУ. Серия: Право. 2012. Том 8. Выпуск 2, pp. $262-273$.

39. Полное собрание законов Российской империи (ПСЗРИ), Собрание 1-ое, Типография II Отделения Собственной Его Императорского Величества Канцелярии, СанктПетербург, 1830.

40. Полное собрание законов Российской империи (ПСЗРИ), Собрание 2-ое, Типография II Отделения Собственной Его Императорского Величества Канцелярии, СанктПетербург, 1830 - 1885.

41. Полное собрание законов Российской империи (ПСЗРИ), Собрание 3-е, Государственная типография, СанктПетербург, 1885 - 1916.

42. Самарин, Ю. Ф., Окраины Россіи. Серія первая. Русское Балтійское поморіе. Выпускъ I, Прага, 1868.

43. Сводъ мъстныхъ узаконеній губерній Остзейскихъ. Часть первая. Учрежденія. СанктПетербург, 1845.

44. Сводъ мъстныхъ узаконеній губерній Остзейскихъ. Часть вторая. Законы о состояніяхъ. СанктПетербург, 1845.

45. Сводъ мъстныхъ узаконеній губерній Остзейскихъ. Часть третія. Законы гражданскіе. СанктПетербург, 1864.

46. Уложеніе о наказаніяхъ уголовныхъ и исправительныхъ. Санкт-Петербург, 1845. 